\title{
Religious Fanaticism and National Security in Nigeria
}

\author{
Oduwole Tajudeen A \\ Department of Sociology, Houdegbe North American University, Republic of Benin \\ Fadeyi Adebayo O. \\ Department of Sociology, Lagos State University, Ojo, Lagos State, Nigeria
}

Accepted: December 17, 2012 Published: June 26, 2013

Doi:10.5296/jsr.v4i1.3161ＵRL: http://dx.doi.org/10.5296/jsr.v4i1.3161

\begin{abstract}
Religion is a social diachronic of special interest that has orchestrated unbridled internecine conflicts and insecurity in Nigeria. The thrust of this paper is propelled by the ferocious and colossal eruptions of religious conflict occasioned by extreme display of religious fanaticism and intolerance. In addition to an unprecedented quantum of self-acclaimed "Men of God" who are catalysts of commercialization of religious institutions and fast eroding religious values, thereby engendering high propensity of insecurity in the society. This paper examines the various factors that have caused religious fanaticism and violent conflicts in Nigeria and their implications. Added to these are the implications of disenchanting religious values, desecrating religious institutions which undermine security in Nigeria. This research work argues that the most crucial factors that have occasioned religious fanaticism and insecurity in Nigeria include the nature of religion itself, diversely conflicting interpretations of doctrines within the same religion, aggressive evangelism, and high level of poverty ravaging the land, a surge in self - serving - "men of God" devouring their prey, among others. The consequences of not promoting positive religious values, retrogressing religious institutions is the wanton destruction of men and properties. To this end, the issue of secularity in a multi ethnic Nigerian society is discussed. To effectively address religious values, fanaticism and insecurity in Nigeria, the paper advocates addressing and promoting poverty alleviation, engendering absolute secularism, provision of adequate security apparatus (both manpower and technological mechanism) and institutionalization of all functional needs of the society.
\end{abstract}

Keywords: Religious values, Institutionalization, Fanaticism, Security, Functionaries.

\section{Introduction}

As Nigeria takes a firm holds with the problem of creating enduring democratic culture, religious fanaticism and insecurity, continue to undermine efforts at leading the nation out of the socio-economic and political doldrums. The spate of Maitatsine riots of 1980 in Northern Nigeria marked the beginning of the trial of this religious orgy in Nigeria. It is estimated that the maitatsine uprising in Kano in 1980 alone claimed over 4,177 lives, while that of Jimeta 
in 1984 and Rigasa in Kaduna in 1992 led to 763 and 175 causalities respectively (Ikenga Metuh, 1994).

Nigeria is a multi - ethnic nation with diverse cultural groups that are about three hundred and seventy four groups in number. Rather than harnessing our diversities towards sustainable national development, we have become slaves to our ethnic origins to which our allegiance is largely focused at the detriment of nation building. Fanatical ethnic consciousness has resulted into ethnic prejudice and mistrust, religious and political diversities, and socio - cultural conflicts. These vices have pervaded all spheres of life in Nigeria, be it employment, education, health, economic and other institutions.

However, a number of questions concerning the evolution and practice of religions in Nigeria particularly since the advent of Islam and Christianity can be raised. What are the causes of religious fanaticism in Nigeria? As a multi - religious state, is the practice of secularity possibly in Nigeria?

A crystal understanding of the problem and dynamics of religious fanaticism and security in Nigeria must be preceded by dealing with religion, fanaticism and security as separate concepts before coming to terms with the close association between religion fanaticism and security. The paper begins with the concept of religion.

\section{Religion}

Religion has been defined in many ways by different people depending on their orientation and perception. Bohannan (1969) sees it in a narrow sense to refer to a particular group. While Bliss (1972) perceived it in a broad sense for the belief systems, moral norms and values held by members of the society. The foregoing depicts that religion is a difficult concept to define as observed by (Pratt, 1947; \& Alannamo, 2004). However, peter (1998) defines religion as a system of symbols which act to establish powerful, pervasive and long lasting moods and motivations in man by formulating conceptions of a general order of existence and clothing these conceptions with such an aura of factuality that the moods and motivations seem uniquely realistic. Durkheim (1915) defines religion to be a unified system of beliefs and practices relative to sacred things, that is to say things set apart and forbidden beliefs and practices which unite into one single moral community and all those who adhere to them. The definitions of religion given by both Peter and Durkheim are characterized by the system of beliefs and practices or conceptions relative to a transcendent being, which unite the people into one fervent moral community, a necessary ingredient for religious fanaticism. This makes their definitions germane to our endeavour.

\section{Fanaticism}

According to Hornby (1988) fanatic person is who is too enthusiastic about something. Fanaticism therefore can be referred to as over enthusiasm. Religious fanaticism, according to 
Balogun (1988) is a violent and unreasoning religious enthusiasm.

\section{Security}

Is the degree of protection to safeguard a nation, union of nations, persons or person against danger, damage, loss, and crime. Security as a form of protection is structures and processes that provide or improve security as a condition. The Institute for Security and Open Methodologies (ISECOM) in the OSSTMM 3 defines security as "a form of protection where a separation is created between the assets and the threat". This includes but is not limited to the elimination of either the asset or the threat. Security as a national condition was defined in a United Nations study (1986): so that countries can develop and progress safely.

\section{Causes Of Religious Fanaticism And Insecurity}

It is a heart perturbs understanding that religion whose elementary function is to unite people together in peace and affection has catalyzed so much conflicts and wars leading to untold destruction of man and property in the society. Many factors are responsible for this religious fanaticism and insecurity in the society. These include; religion itself, differences in interpretation of the doctrine within religions, aggressive evangelisms, the claim to monopoly of religious truth and poverty.

The Co-existence of conflicting and mutually intolerant religious results in religion being a divisive force in a society. For instance, when Christianity started its penetration into the Mediterranean world, it resulted in a serious clash between it and Islam. This led to the Christian crusades to regain the control of Jerusalem. Equally, the spread of Islam to Syria, Asia Minor, Spain and Sicily was seriously resented by Christian Europe. The fear of Islam penetrating made the Byzantine Emperor to appeal to Pope Urban II for assistance against the spread of Islam in 1095. The Pope at Claymont in South - East France appealed to all Christians to join hands together and halt the advent of Muslims.

The United Christian Forces recaptured. Jerusalem from the Muslims in July 15, 1009 AD, which the Muslims took back in 1187 (Hitti, 1960). The struggle for the possession and control of Jerusalem has continued unabated until 1971 when the Baifour Declaration founding the Jewish national in Palestine was made, and the subsequent independent of state of Israel established on May 14, 1948 (Elliot and Summerskill, 1975). This has not stopped the crisis in the Middle East. The region has become the scene of vicious fighting, sniper action and terror, as each religion struggles to gain control.

In Nigeria the story is not quite different. Islam was introduced into the country from the Middle East through the North, while Christianity came through the sea to southern Nigerian as has been noted. Both Islam and Christianity have spread southward and northward respectively meeting them in the middle belt of Nigeria and have made efforts to permeate other's territory. Mutual suspicious, tension and outright hostility have characterized their relationship in the 
nation as each struggles to gain a foothold in the other's domain. The suppressed dissatisfaction with and anger at each other began to manifest overtly in the 1960's. Religious fanaticism and violence have been caused by diverse interpretations of doctrine within the same religion. A classic example is the Protestant Reformation that culminated in various wars in Europe, namely; French wars of Religious 1562 - 1610 lands revolt 1578 - 1609, and the Thirty years war between Catholic and protestant states in Europe 1618 - 1648 (Stewart and Glynm, 1981). Islam is also bedeviled by the evil of the mutually intolerant interpretation of the same religion in Islam including the Kharijites who held the view that the leadership of the Muslim community neither belonged to some branch of Muhammed's family (SAW) not to a certain Arab tribe, but to the one best qualified for it.

Ali for better clarification state that:

The mosque of Muhammed, like the church of Christ, as been rented by intensive divisions and strives. Difference of opinion on abstracts subjects, has always given rise to greater bitterness and a fiercer hostility than ordinary differences on matters within the ranges of human cognition, the disputes regarding the nature of Christ deluged the earth with the blood of millions, the question of free will in man caused, if not the same amount of bloodshed, equal trouble in Islam. (Ali, 1980:295).

Another factor that has helped to cause religious violence is aggressive or militant evangelism. The adherents of scriptural religious such as Christianity and Islam often employ offensive or coercive approach in the conversion of converts and the general propagation of their religious faith. The preachers usually apply derogatory terms on unbelievers such as infidels or pagans. Christians and Muslims alike are guilty of coercive preaching that has precipitated violent outbursts in Nigeria. A lucid example is the March, 1987, religious violence at the college of education, Kafanchan, which spread to Katsina, Funtua, Zaria, Daura and Kaduna. This was occasioned by an allegation of apostably blasphemy, heresy, and misinterpretations of the Holy Quran by Evangelist Bello Abubakar, in Kano in which Thirty - One persons died, several wounded and property worth millions of naira destroyed.

Another important factor that causes religious violence in the society is the claim to monopoly of religious truth and practice, the tendency of the member of that group is to ignore what ever truths are contained in other religious (Ekwenife, 1993). This sows the seed of religious intolerance. In Nigeria, both Muslims and Christians have demonstrated the inability to recognize and accommodate the beliefs and truths of others, leading to avoidable severe religious conflicts.

The unbridled action of the press through its junk journalism and sensational headlines has on anti - miss world beauty pageant riot, caused by “This Days" offensive publication on Prophet Muhammed (S.A.W.), is a living example. The violence occurred in Kaduna, on November 22, 2002, between the Muslims and Christians in which over 200 people were killed with several injured. 


\title{
Ml Macrothink
}

Obateru (1994) has observed that the problem of grinding poverty, dearth of in-depth knowledge of religion, especially in the urban areas also accounts for most violence experienced in Nigeria. Poverty dehumanizes and frustrates a human being, and makes him/her prone to confliction actions. He/She is ever ready to take his turn on the society. Recent bloody clash in Kaduna (22nd November, 2012) over a wrongful Islamic inscription by a local tailor on one Muslim dress. This was misconceived by some Muslim youths, a blasphemy on Islam as a religion, pandemonium ensued, one killed, several others severely injured, scores of shops were burnt. It is a palace statement - "two wrongs do not make a right".

Highly susceptible to the evil influence of the haves to physically participate in violent conflicts. The example of the "Talakawas", or the "Almageris" in the Muslim societies, is an easy source for fueling crises in the Muslim dominated areas.

\section{Secularity In Nigeria}

The theory of secularization is a classical sociological tenant in which secular norms (Laws) replace religious principles in the organization of society. Secularization is imperatives for the rationality that enhances modernization and political advancement. The theory is motivated by the idea of the sovereignty of the people.

Secularization, as a social process, leads to a reduction or religiosity, membership, social influence, wealth and prestige of religious organizations. However, the contrary is the case in many multi - religious stages.

In Nigeria, the level of religiosity is very high with an increasing intensity of religious belief, practice and passion. The application of religious principles or law in the polity is acquiring a pernicious dimension in disregard to the secular law. Nigeria's characteristic pluralism in religious makes a neutral arbiter, the secular state imperative, survival of those of others minority faiths and a threat to the legitimacy of the state. This is why secularity was made a constitutional issue in 1979, which says in section 10 that "The Government of the federation or state shall not adopt any religious as a state religion". But in section 35 of the same constitution it was position that:

\author{
Every person shall be entitled to freedom \\ Of thought, conscience and religion \\ Including freedom to change his religion \\ Or beliefs and freedom ... to manifest \\ And propagate his religion or belief \\ In worship, teaching, practice and observation.
}

A critical examination of the two sections of the constitution quoted above concerning secularity in Nigeria will show obvious contradictions. State in secularism in Nigeria has not only been improperly defined but has also been the source of the inconsistencies observed in 


\section{$\Lambda$ Macrothink}

the practice of secularity in Nigeria. The organization of annual pilgrimages to Mecca and Jerusalem with public funds and the establishment of national religious councils by a secular Nigerian State are some of the examples of the inconsistencies The maintenance of diplomatic representation to the Vatican and the tacitly joining of the organization of Islamic Countries, OIC by the Nigerian State could be explained by the constitutional provision on secularism. Ethnic and religious issues are part of the most recurring issues in Nigeria's body security. The issues has permeated the landscape since the colonial period and up till the present time, there seems to be no solution in sight to the accompanying conflicts of ethnic rivalry and religious intolerance. The dominant and minority ethnic groups treat each other with suspicious and the different religious worldview clash at the slightest provocation.

The current political cum religious battles is fuelled by certain quarters and individuals who benefits at the expense of the state and citizens. According to international institute for Democracy and Electoral Assistance (2011) asserted that "Numerous actors have a stake in the promotion of ethno-religious conflicts because the associated arithmetic of numbers under planning the conflict translates into jobs, contracts, the creation of local government and states as well as representation in the National assembly".

In Nigeria, what explanation do we have for these colossal losses of lives and properties as shown in cross-sectional portraits below?
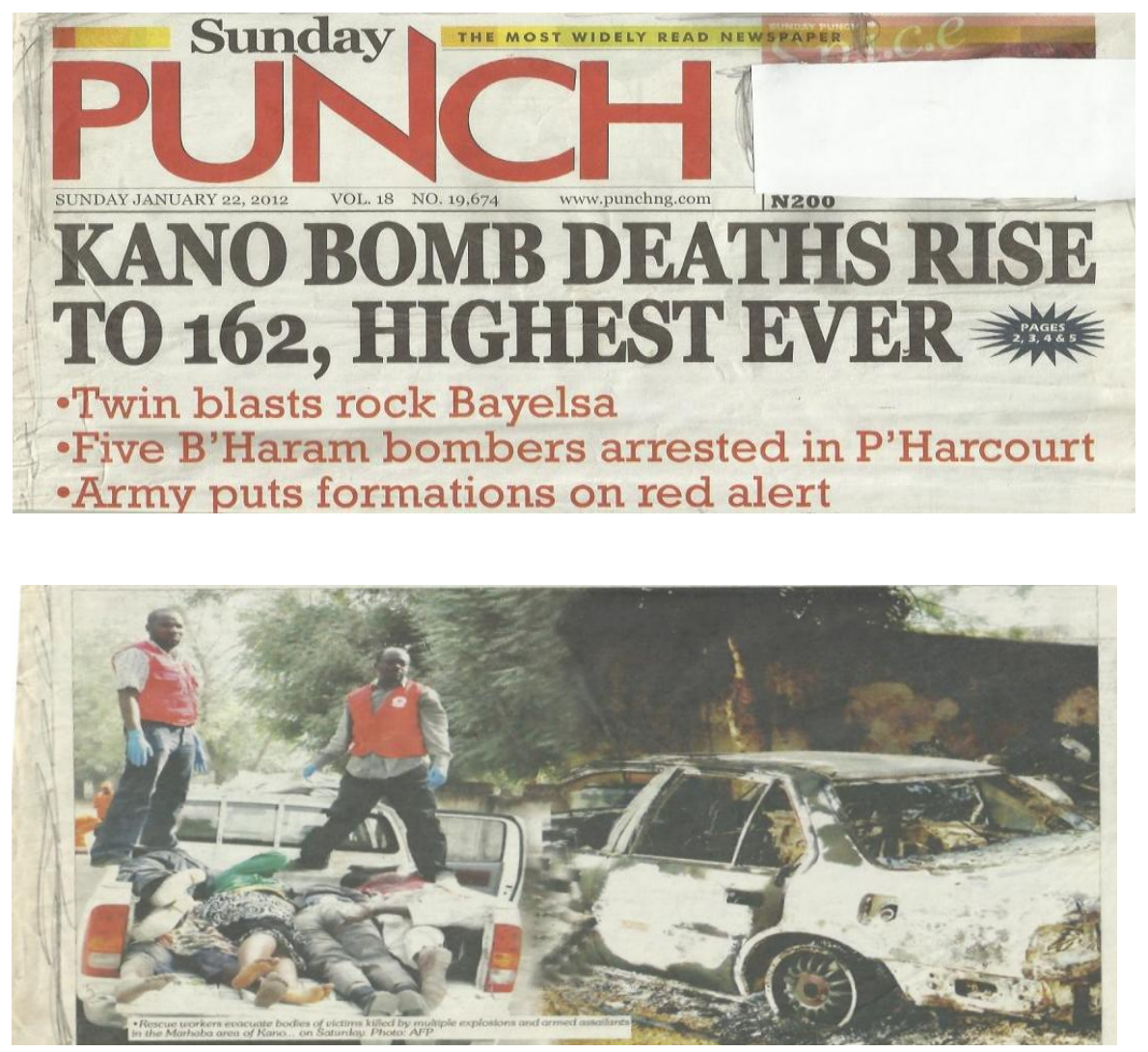

Source: Nigerian Tabloid, The Punch, Sunday, January 22, 2012 
The unprecedented quantum and dynamism of insecurity in Nigeria recently and still re-occurring (bomb blast) killing innocent persons and destruction of properties is beyond imagination of an average Nigeria citizens. Better still, how would the country explain this level of destruction in the name of religion?
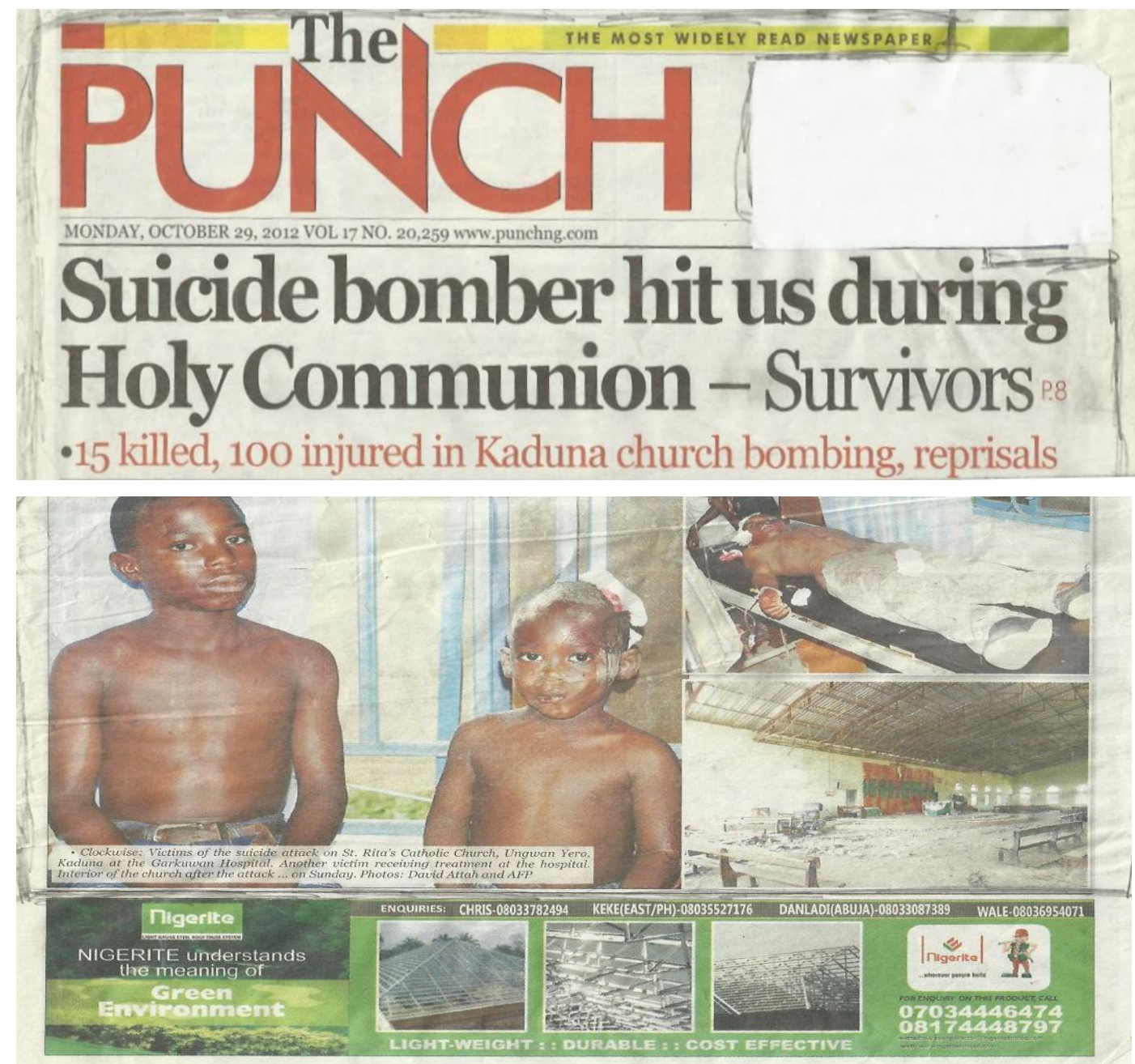

Source: Nigerian Tabloid, The Punch, Monday, October 29, 2012

\section{The Implications Of Religious Fanaticism And Security}

The implications of religious violence in any society are varied. Perniciously devastating and outrageous. It has grave consequences on the victims and perpetrators, as well as the entire society. Religious violence stereotypes a religious community, a stigma that reduces the acceptability of and support for that religious group.

A most painful consequence of religious violence is the reckless destruction of live and property. It is a painful outcome of religious fanaticism and violence because no known scriptural religion tolerate murder, but at the slightest act of provocation, many religious bigots and fanatics deploy the latest and most sophisticated weapons of war available to destroy and 
maim human beings. The cherished belief in the sanctity of human life and the right to life of the individual has been to question by the various religious orgies in contemporary Nigerian society.

The frequency and the increasing intensity of religious violence characterized by colossal destruction of human and material resources have become appalling to every right thinking Nigerian. One immediate consequence of religious violence is the disruption of socio-economic life of the people. Most religious violence in Nigeria arises unanticipated, cutting of family members and relations, and sometimes producing widows and orphans. As people escape the pogrom and hide for their lives, the economic life of the society suffers. Violent religious conflicts have the potential of resulting in large scale physical displacement and forced relocation of individuals, families, and groups with all its torments (Egwu. 2004).

A significant consequence of all violent conflict, including religious violent conflicts, is the emergence of a hostile environment unfavourable for investment. An insecure and violence-ridden polity can not attract a meaningful investment, including foreign investments. Apart from the fact that the society is declared a security risk area, where no investor would want to venture, the socio-economic infrastructures that create enabling environment for investments and development are destroyed during the violent conflicts.

Development and growth would be retarded as development and growth can only take place under a peaceful atmosphere.

\section{Towards A Solution To Religious Fanaticism And Security In Nigeria}

Violent conflicts have been catalyzed world over by the joint influence of various factors, or a single identifiable factor. The last case is very uncommon. Often, a prominent factor among others is identified with the causation of a particular violent conflict and the violent conflicts take the name of such a factor, such as religious violence. The Nigerian plural society, given its numerous ethno-religious groups with varied characteristics and interest, is a fertile ground for the joint influence of different factors in orchestrating violence. In this exercise, it will be pertinent to recognize the complex plural nature of Nigeria at various facts of life such as religion, ethnicity, education, economic, politics e.t.c. in advancing solutions to religious fanaticism and violence. As argued by Alanamu (2004), there is no way we can escape pluralism and secularism in our attempt to solve the problem of religions violence.

Balogun (1988) suggested that the Federal Government should give a strict and comprehensive reinterpretation of Nigeria's secular status. These writers are in agreement with this suggestion and urges that quick action be expedited on the issue. He further suggested that Nigeria should be recognized not as absolutely a secular state but a multi - religious state that respects the peculiarities of all religious believers in the country. This suggestion begs the questing. Otite (2001) argues that absolute secularity is a necessary component of any plural society with high levels of religious participation in diverse religion... as the conflicts in the society will not 
be able to resolve on the basis of religion. Balogun (1988) has noted that the mutual suspicion, tension and outright hostility that characterized the relationship between believers of different religions, is as a result of the dose of indoctrination imparted to the members of the different religious groups. When he posited:

The history of religion in our schools shows that, in the main, the teaching of religion by various bodies is seen as an arm of the evangelical work. Thus a child goes to school to receive other Christian religious education or Muslims religious education depending on the schools foundation. Each religious faith tries to assert its supremacy by trying to refute the claims of another. Products of such type of education grow up to be at peace and love with the religion in which they have been indoctrinated in schools, at war and discord with other religions.

It is common knowledge that when such religious bigots are in positions of authority, they discriminate against members of other religious in employment, admission issues, policy making and implementation, award of scholarships to students, representation of the nation at all levels, at the dissatisfaction and anger of other religious adherents. It is here recommended that over-emphasis on the exclusive of religious viz a viz other religious be discouraged. We advocate greater ecumenism of religious to enhance better understanding and appreciation of the religion's views for a greater peaceful co-existence. At the institution of higher learning, a campaign for greater inter religious awareness and tolerance be mounted by the institution's authorities. This should be achieved through various ways including symposia in which students and teachers are constantly brought together to reflect on the values of religious tolerance in a multi - religious community.

In the contemporary world, dialogue has become a veritable instrument for the resolution of many intractable problems, and our nagging religious violence may not be different. The use of dialogue to resolve our religious problem should be encouraged at all levels. In our tertiary institutions, the authorities should ensure that every religious group has a place of worship and religious renewal. Strict laws should be put in place to regulate religious fanaticism and promote peace, unity and mutual cooperation among different religious groups in the campuses. Additionally, Alanamu (2004) advocates the need for conscious effort to confront the problems associated with the political mobilization of religious identities through political engineering.

Mohammed (1990) sees this as the fine-tuning of constitutional reforms and structures through the existence of a deliberate and well-considered constitutional choice in the search for a new, and by implication, more viable and durable structures and institutions that can withstand the stresses of the competitive demands of our national life. Adebisi (2002) has called on Nigerian leaders to address more dedicated the problem of educational imbalance between the North and South, as a means of reducing religious violence, as this will help to reduce the different rates of development between the two regions. The poverty alleviation programme at all state levels 
is a welcome development as that would make for a more egalitarian society and reduce religious intolerance and violence. Our advocacy is that, it should be more grass-roots and mass oriented for effect. Also, the need to reduce the problem of religious fanaticism and violence has made the pursuit of democratic governance that respects individuals and group rights while emphasizing innovative and productive politics imperative.

The Nigeria press, as an informative organ, owes the nation the practice of objectivity in journalism. In the recent past the subjectivity of the press in reporting religious matters has plunged the nation into the darkness of religious violence. It is expected that the mass media practitioners should always imbibe the ethics of professional journalism in reporting or making news analysis and features. This will go a long way in preventing religious uprising and severe conflicts in Nigeria. One important factor in the reduction of religious fanaticism and violence is the possession of an effective and efficient security network. In this conation, our security operatives should be adequately trained and equipped to tackle the problem of religious fanaticism and violence and nip them in the bud. There should be adequate policing of our boarders, and cities that are prone to religious violence.

\section{Conclusion}

Ferocious and colossal eruptions of religious pogroms occasioned by extreme display of unbridled religious fanaticism and intolerance have continued to undermine proactive efforts at leading Nigeria out of the socio - economic and political doldrums. The history of religious conversion in Nigeria by both Christian and Islam has been closely linked to the control and use of state power. One distinguishable constant or communality in evangelical episode in Nigeria is the chime and orchestration of fanatical and aggressive evangelism. Various factors have been identified to cause religious fanaticism and insecurity. These include religion itself, the co-existence of conflicting and mutually intolerant religions, diverse interpretations of doctrine within the same religion, aggressive or militant evangelism, the claim to monopoly of religious truth, the action of the press and grinding poverty of the people. The secularization of Nigeria is hampered by the ambiguity in the provision of the Nigeria constitution concerning secularity. The implications of religious fanaticism and violence in Nigeria were dealt with. A most painful consequence of religious fanaticism and violence is the reckless destruction of lives and property. Other consequences include the disruption of socio-economic life of the people, the emergence of a hostile environment for infotainment and the creating of an enabling environment for military intervention. Solutions to religious fanaticism and violence in Nigeria were advanced. Secularity in Nigeria was seriously canvassed among others. We conclude with a clarion call, to all stakeholders in the Nigeria enterprise not to allow religious fanaticism and violence, to let the Nigeria house crumble, so that we will not grumble in the shamble. 


\section{References}

Adebisi, M. A. (2002) Ethnic Relations and Politics in Nigeria in Igun. U. A. \& Mordi A. A (ed) Contemporary Social Problems in Nigeria. Ijebu Ode: Shebiotmo.

Alanamo, S.A. (2004). Reflections on religious violence in Nigeria $(1999$ - 2000) in

Ali, S. A. (1980). The Spirit of Islam: New Delhi.

Atlanamo, S. A. (eds) Issues in political violence in Nigeria. University of Ilorin Press.

Balogun, K. A. (1983), Religious intolerance Harmony and Nation Building in Jolayemi. E.T. (eds). Leading Issues in General Studies, Humanities and Social Sciences. Ilorin: Department of Religious, University of Ilorin.

Bashir, A. (2002). Religious intolerance Harmony and Nation Building in Jolayemi E. T. (eds). Leading issues in General Studies, Humanities and Social Sciences. Ilorin: The General Studiovision University of Illorin.

Bliss, K. (1972). The future of religion. Pelican Books.

Bohannan, P. (1969). Social Anthropology, London Holt, Rinchart and Winston

Durkheim, E. (1915). The Elementary forms of the religious life. Trans. J. W. Swain London and Union.

Egqu, S. G. (2001). Ethnics and Religious Intolerance in Nigeria. Jos: St. Stephen Inc. Book House.

Ekwenife, A. (1993). Politics and Religious Intolerance. The Nigeria situation in Abubakar. R. D. (eds) Religion and politics in Nigeria. Nigeria Association for the study of Religious.

Elliot, F. \& Summerskill, M. (1975). A Dictionary of politics. England: Penguim Books Ltd. Guardian, $11^{\text {th }}$ December 1999, p.16.

Hitti, P.K. (1960). History of the Arab London: Macmillan

Hornby, A. S. (1980). Oxford Advanced Learners Dictionary of current English. Oxford: Oxford University Press.

Ikengah - Metuah, E. (1994). Two Decade of religious conflict in Nigeria: A recipe of peace. Bulletin of Educational Theology. Vol.6 p.1

Mohammed, A. (1990). Political Engineering in Nigeria: Past Experience Problems and Prospects: NPSA Annual Lecture N.T.A. 28 September (2004). National Concord vol. 4, No. 1253

Obateru, O. I. (1994). Planning the city to urban violence in Albert, I.O. (e.d) Urban Management and Urban Violence in Africa Vol. 1 Ibadan: IFRA

Parts, J.B. (1947). The Religious Consciousness. London: Macmillan

Peter, V. V. (1988). Religion in Bernard (eds) Encyclopaedia of social and cultural Anthropology.

Steward, E. W \& Glyan, J. A. (1981). Introduction to Sociology. New Delhi

\section{Biographical Notes}

Adebayo O. Fadeyi is an Associate Professor in the Department of Sociology, Lagos State University, Ojo, Lagos State, Nigeria. Tel: +234(0)8062331394.

e-mail: fadeyi2@yahoo.com 
Tajudeen A. Oduwole is a lecturer in the Department of Sociology, currently the Head of Department, Houdegbe North American University, Route de Porto - Novo, Cotonou, Republique du Benin. His research interest includes administrative reforms, public policy analysis, development administration and sustainable governance. He is equally a $\mathrm{PhD}$ student in the Department of Sociology, Lagos State University, Ojo, Lagos State, Nigeria. Tel: +234(0)8037140814, (0)8074000361 and +229(67086446).

e-mail: toduwole1@yahoo.com 